See discussions, stats, and author profiles for this publication at: https://www.researchgate.net/publication/332977319

\title{
Validating a New TQM-Benchmarking Measurement Model in an International Humanitarian Setting
}

Article in Nonprofit Management and Leadership · May 2019

CITATIONS

0

5 authors, including:

Ali B. Mahmoud

University of Liverpool

47 PUBLICATIONS 90 CITATIONS

SEE PROFILE

Leonora Fuxman

St. John's University

18 PUBLICATIONS 48 CITATIONS

SEE PROFILE

Some of the authors of this publication are also working on these related projects:

Vocational interests of youth in Ecuador View project

Technology adoption in organization View project
READS

237

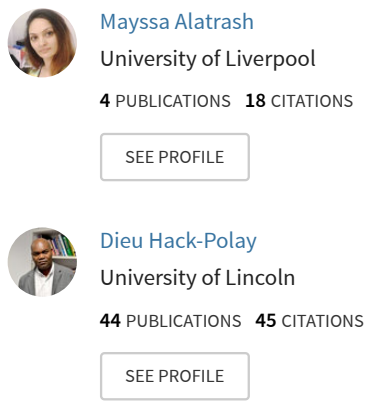


Nonprofit Management \& Leadership

WILEY

Validating a New TQM-Benchmarking Measurement Model in an International Humanitarian Setting

\begin{tabular}{|r|l|}
\hline Journal: & Nonprofit Management \& Leadership \\
\hline Manuscript ID & NML-18-0113.R3 \\
\hline Wiley - Manuscript type: & Research Note \\
\hline Keywords: & $\begin{array}{l}\text { Human Resources, Nonprofit < Management, Performance }< \\
\text { Organizational, Empirical < Research, Quantitative < Research }\end{array}$ \\
\hline
\end{tabular}

\section{SCHOLARONE ${ }^{\text {M }}$ \\ Manuscripts}

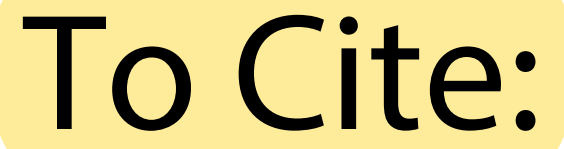

Mahmoud, A. B., Alatrash, M., Fuxman, L., Hack-Polay, D., \& Grigoriou, N. (2019). Validating a New TQM-Benchmarking Measurement Model in an International Humanitarian Setting. Nonprofit Management \& Leadership, In press. 


\title{
Humanitarian Setting
}

\author{
Ali B. Mahmoud
}

Mayssa Alatrash

Leonora Fuxman

Dieu Hack-polay

Nicholas Grigoriou

\section{Abstract}

The research aims to empirically validate a multi-dimensional measure of total quality management (TQM) benchmarking within a humanitarian setting. This study is the first to investigate the dimensionality of the TQM benchmarks as used by international nongovernmental organisations (INGOs). The proposed four-dimensional construct for measuring quality lends itself to lean and practical TQM framework for INGOs, allowing them a greater awareness and an appetite for aligning their operations with TQM principles. Utilizing survey data collected from participants working for United Nations agencies in the Middle East, the methodology consisted of a set of literature-backed quantitative procedures to test the validity of the previously suggested theoretical TQMmeasurement model. An alternate model emerged and revealed that the TQMbenchmarking measurement model is a four-factor variate. The implications of the proposed model for implementing lean management practices by INGOs are discussed. 
Keywords: Total Quality Management, Benchmarking, Measure, Validation, International Non-Governmental organization, Humanitarian sector, Middle East 


\section{Introduction}

A large body of the Total Quality Management (TQM) scholarly work has focused on the private sector with numerous evidences linking TQM and organisational performance. While extant research reveals that TQM is a vital methodology to improve corporate performance and sustainable competitive advantage (e.g., Al-Dhaafri \& Al-Swidi, 2016; Boateng-Okrah \& Fening, 2012), most of the research has focused on profit driven organizations. Less is known about how TQM is linked to performance in the non-profit sector, particularly within humanitarian organizations.

Pressured by donors and the mainstream media to optimize performance and improve accountability, humanitarian agencies started exploring the use of private sector proven management philosophies. In this context, many international initiatives aiming at improving the quality of international humanitarian assistance through focus on both donor and beneficiary satisfaction have emerged (Campbell, DiGiuseppe \& Murdie, 2019).

Yet, there is no scholarly consensus on how to measure the quality of humanitarian assistance. One recently proposed TQM-Benchmarking model (Sweis, et al., 2016) emerged as a conceptual framework that was specifically developed to assist international nongovernment organizations (INGOs) to carry out their interventions effectively and efficiently.

The TQM-Benchmarking model (Sweis, et al., 2016) offered a six-dimensional framework for improving INGOs performance while satisfying donors and beneficiaries: 1) Leadership and Management Commitment; 2) Beneficiary Focus and Participation; 3) Partnership Quality Management for Sustainability; 4) Human Resource Focus; 5) Process Management, Learning and Continuous Improvement; and 6) Use of Quality Information. While the model was derived from extensive literature reviews of TQM practices in private sector as well as practical adoptions of TQM in humanitarian relief settings based on two major 
INGOs located in Jordan, the research offered no validation or evaluation for the proposed framework. The authors attempted to adapt each of the six identified dimensions to the specifics of TQM implementations for INGOs while conforming to the principles of TQM. Since this exercise has seldom been done (Paton, Foot \& Payne, 2000), our research represents a significant contribution to the field of international humanitarian assistance.

The objective of the research is to continue the previous efforts by focusing on providing empirical evidence to validate the TQM-Benchmarking measurement model. Utilizing a survey instrument, we evaluate the extent to which the UN agencies located in the Middle East employ the six dimensions of the TQM-Benchmarking model. In the process of validating the previously developed model, an alternate more-streamlined model emerged and was tested using an exploratory factor analysis which revealed that the TQM-benchmarking measurement model is indeed a four-factor variate.

\section{Literature review and hypotheses}

\section{TQM implementation in humanitarian NGOs}

While TQM has long been accepted as a prevalent management paradigm (Hackman \& Wageman, 1995), little is known about its adoption or implementation from an international NGO perspective (Sweis et al., 2016; Baidoun, Salem \& Omran, 2013). Indeed, most early applications of TQM were in industrial firms, where the quality of goods or products is relatively easy to measure via quantitative tools (Kearns, Krasman, \& Meyer, 1994). As with other managerial thoughts and practises, quality management has made some effort to move from its unique home in for-profit businesses to the non-benefit world (Cairns, Harris, Hutchison, \& Tricker, 2005). TQM, with its emphasis on continuous improvement to achieve customer satisfaction and long-term organizational success, promotes an integrated process 
improvement approach encompassing all the departments of the organization (Baidoun et al., 2013). Emphasis on customer satisfaction, continuous improvement, problem-solving processes and employee empowerment (Zbaracki, 1998) lends TQM as one of the most obvious ways for organizations (profit and non-profit) to reduce costs and enhance revenues (Horng \& Huarng, 2002). In the same perspective, Suykens, De Rynck \& Verschuere, (2018) argue the potency of systematic private-sector like measurement in non-profit management. NGOs have borrowed several practices from the private sector, e.g. benchmarking, strategic planning, supply chain, customer service/care, etc., suggesting that TQM should not be an entirely alien concept for voluntary sector organizations.

The lack of TQM application in international humanitarian organizations is surprising given that such organizations have a long history of responding to people in need and are important players in the international community's response to emergencies (Ferris, 2005). According to the Yearbook of International Organizations, the number of INGOs more than quadrupled from 1990 to 2000 (cited by Ferris, 2005, p.312). International humanitarian organizations are not exempt from the challenges of the modern competitive business environment which is characterized by fierce competition and increasingly demanding customers (Hack-polay \& Igwe, 2018; Sweis et al., 2016). Competing for scarce resources in an overcrowded NGO market requires a strategic approach in order to ensure effectiveness and sustainability. To this end, a number of business models for NGOs have been suggested, including those focusing on efficiency measurement (Baidoun, et al., 2013; Development Initiatives, 2016), those focusing on performance measurement (Hughes, 2013) and those suggesting a stricter financial accountability (Ryan \& Irvine, 2012; Stirrat, 2006).

The limited take-up of TQM in NGOs might be explained by several intertwined dynamics. Baidoun, et al. (2013) found that organisational cultures within NGOs are not always 
supportive of critical approaches such as TQM. This is inextricably linked to the fact that many workers in these organisations are perceived as volunteers giving time that is not always commensurately rewarded. Therefore, any structured approach to managing performance could deter volunteers. Hack-polay \& Igwe (2018), in turn, find that implementation of some aspects of TQM is associated with the insufficiency of personnel and funding pressures; this argument is prevalent in the NGO literature (see also Daar et al., 2018; Saavedra, \& Knox-Clarke, 2015; McGoldrick, 2011). Another significant barrier to embracing TQM in NGOs appears to be associated with the limited independence of some of the key organizations in the field. This could be influenced by the institutional context (Campbell, et al., 2019; Dany \& Schneiker, 2015; Donini, 1995), by funder priorities (Vaux, 2006); or by political pressure (Vaux, 2006; Porter, 2003) which constrain humanitarian organisations into particular types of behaviour and management, especially when the agencies are involved in humanitarian action conflict zones. A further barrier to the implementation of TQM outside the business world is associated with its theoretical complexity, which may lead to loss of focus, excessive paperwork and more complicated procedures (Dahlgaard et al., 2013).

Accordingly, we formulate Hypothesis 1 to test the extent of the use of TQM practices within the surveyed audience of UN agencies.

Hypothesis 1: UN agencies exhibit positive levels of TQM practices.

\section{TQM-Benchmarking model}

Since our study aims to validate the six dimensions of the TQM- Benchmarking model formulated by Sweis, et al. (2016) within the international humanitarian setting, each of the six dimensions is discussed below. 
Leadership and management commitment. Leadership and management commitment to TQM have found academic support among many prominent quality scholars (Gherbal et al. 2012). The findings suggest that leaders and decision-makers have the responsibility to manage the vision, mission, and strategy for the benefits of the organization and its performance.

Fonseca (2015) advocates that senior management commitment is one of the core principles of TQM since senior management plays a vital role in supporting the process required to successfully achieve quality through commitment, leadership style, and encouragement. Furthermore, senior management is accountable for the level of organizational performance (Valmohammadi, 2011), as well as being responsible for creating the work environment, culture, and framework of operations within the organization. Therefore, the managers must align their practice to the tenets of TQM and demonstrate commitment to it (Boateng-Okrah \& Fening, 2012).

Beneficiary focus and participation. Gherbal et al. (2012) stress that quality could be obtained through the customer's satisfaction in the context of the private sector and through the beneficiary's satisfaction in the context of the humanitarian sector (see also Griekspoor \& Sondorp, 2001). Therefore, the beneficiaries should be regarded as the primary stakeholder because they not only benefit from the services provided by the organization but have the right to be involved in the design of the intervention and be part of the decision that affects their lives (Wellens \& Jegers, 2014).

The appropriate assistance and the correct timing for delivering humanitarian aid are two of the nine commitments created by the Core Humanitarian Standard on quality and accountability (The Core Humanitarian Standard, 2014). These can be achieved by giving the beneficiaries an opportunity to participate in the intervention design, regular need assessment, 
and information sharing, therefore encouraging them to actively participate at various stages of the process.

The beneficiary's satisfaction is not only measured by the quality of assistance but also by how they receive this assistance, which means that the process and system followed by the organization are important in satisfying the beneficiaries. Therefore, the internal stakeholders (the employees) should be aware of this and should be committed to the quality, both of which can be cultivated by the top management via appropriate leadership style.

Human resource focus. Human resource focus is one of the Malcolm Baldridge National Quality Award dimensions (MBNQA) (Tickle, Mann, \& Adebanjo, 2016) and as such represents a vital factor that affects organizational performance. When employees deliver the interventions to the beneficiaries with a high level of performance, the organization meets the beneficiary's satisfaction. Altayeb \& Alhasanat (2014) establish that employees' engagement, training, and empowerment are obligatory for successful TQM implementation, while Analoui \& Samour (2012) find that strategic HR management is the most important factor to improve the strategic performance particularly in non-governmental organizations due to the diversity of actors involved, e.g. paid staff, volunteers and community activists, etc. whose coordination requires more than standard HR processes (Hack-polay \& Igwe, 2018). Ridder, Piening \& Baluch (2012) confirm the rising importance of HR management in a non-profit setting, particularly as a result of funding cutbacks, and the need to serve multiple stakeholders while facing a scarcity of resources. Furthermore, NGOs with sufficient human resource capacity are more likely to seek collaboration than are other organisations to effectively and efficiently respond to challenges that cannot be cracked, or solved easily, by single NGO (AbouAssi, Makhlouf, \& Whalen, 2016). 
Process management, learning, and continuous improvement. Process management is a set of activities that optimize organizational processes, clarify the responsibilities, evaluate performance of the process, and recognize opportunities for continuous improvement (Wienclaw, 2017). One of the most important aspects of process management is re-engineering, which gives the organization the opportunity to discover process errors and to identify and remove non-value adding activities, thus supporting the idea of quality because the process can be changed to be more flexible, effective, and efficient (Wienclaw, 2017).

The philosophy of TQM, with its preventive focus, relies on an assessment of organizational processes to identify and correct the cause of failure early. The organization then ensures that the process is designed to deliver the assistance to customer/beneficiary quickly and easily (Yong \& Wilkinson, 2001).

Supporting the virtues of process management, Lassiter (2007) advises non-profit organizations to utilize process improvement. Similarly, Steketee (2010) finds process management to be important for handling managerial problems and social issues. Cheng \& Chang (2012) reveal how the quality concepts, such as the Lean Six Sigma, improve the quality of humanitarian interventions and support the organization to deliver the required assistance within a short time despite limiting resources.

The learning and continuous improvement in the humanitarian setting is one of the six benchmarks of standards listed by HAP (Humanitarian Accountability Partnership, 2010). It is argued that it can best be achieved through diligent documentation, internal monitoring, evaluation and auditing.

Use of quality information. TQM scholars consider information as one of the critical success factors in organizational performance (Gherbal et al. 2012). Furthermore, quality information is one of the dimensions of MBNQA (Tickle, Mann, \& Adebanjo, 2016). The 
attributes of quality information are accuracy, timeliness, appropriateness, reliability, completeness, relevance, as well as the need for information to be cost-beneficial and usertargeted to enable senior management to take a corrective decision (Murtala, 2012) and deliver the interventions at the right time. In an NGO context, information is a key factor in meeting the beneficiaries' needs; thus, information is required in all project/program cycles from planning to completion. Moreover, AbouAssi, et al. (2016) find NGOs with more technological resources are more likely to seek collaboration.

Partnership quality, management for sustainability. The collaboration and cooperation with stakeholders such as local communities, governmental officers, and private companies positively affect the quality of humanitarian interventions (Jacobs, 2011).

Rathi, Given \& Forcier's (2014) research on non-profit organizations shows that partnership means collaboration between organizations to support one another by sharing organizational resources including finance, staffing, experience, and information. Partnerships are beneficial (Buckup, 2012; Jackson, 2012; Samu \& Wymer, 2001 cited by Rathi, Given \& Forcier, (2014, p. 868)), and assist the partner organizations to concentrate on joint objectives (Mandell, 1999), cited by Rathi, Given \& Forcier (2014, p. 868).

According to Proulx, Hager, and Klein (2014), non-profit organizations cooperate to save funds and to share information, and therefore improve humanitarian services. Meanwhile, Fitzpatrick and Molloy (2014) find that non-profit organizations need to create partnerships with local NGOs because the local actors have a better understanding of how to implement humanitarian activities smoothly (Coate, Handmer and Chong, 2006). Collaboration and cooperation allow the humanitarian actors from UN agencies, INGOs, and from local NGOs achieve their common objectives in an effective and efficient manner and avoid the overlapping that might occur. 
Based on the review of the six dimensions of the TQM measurement model, Sweis et al.'s framework can be credited with the merit of attempting to connect each dimension with the NGO context. However, the framework still suffers from theoretical complexity, which hinders the application of TQM in INGOs. Thus, considering the need to validate and evaluate the model, we designed a quantitative instrument to assess the dimensionality of the TQM measurement model (See Figure 1). Hypothesis 2 below posits the six-dimensional construct of the model.

Hypothesis 2: TQM Benchmarking measurement model is a six-factor structure comprising: Leadership and Management Commitment (LMC); Beneficiary Focus and participation (BFP); Human Resource Focus $(H R F) ;$ Process management, Learning and Continuous Improvement (PMLCI); Use of Quality Information (UQI) and Partnership Quality Management for Sustainability (PQMS)

\section{Methods}

\section{PLACE FIGURE 1 ABOUT HERE}

The survey instrument consisting of 27 statements (originally loading on six dimensions) was constructed based on the theoretical framework developed by Sweis et al. (2016) and rated on a five-point Likert scale. Our sample $(\mathrm{N}=1,982)$ was comprised of various grades professional members of staff of the UN organisations operating in Syria, Egypt, Cyprus, Palestinian Territories, Israel, Lebanon, Iran, Iraq, and Turkey. We distributed 1,982 self-administered questionnaires in 2017-2018 and had 739 returned responses prior to data analysis. We followed Covariance Based Structural Equation Modelling (CBSEM) using 
AMOS v. 23 to analyse the dimensionality of the proposed construct and performed a Confirmatory Factor Analysis (CFA) utilizing the returned responses. However, testing the normality of observed variables represents a key condition that should be satisfied before conducting a CFA (Bentler, 2005; Mahmoud \& Khalifa, 2015; Mardia, 1970; Meyers, Gamst, \& Guarino, 2017). Despite the fact that having non-normally distributed observed variables may be linked to a potential breach of the multivariate normality condition, the contrary is not necessarily true (Mahmoud \& Khalifa, 2015). In other words, there might be a chance where the construct lacks the multivariate normality although the representing observed variables are univariate normally distributed (Byrne, 2010; Meyers et al., 2017; West, Finch, \& Curran, 1995). Thus, we tested the variable set against both univariate and multivariate normalities after excluding the cases that caused kurtosis. Additionally, we dropped 232 cases that caused inflation in the critical ratio and the multivariate kurtosis. Subsequently, we had critical ratios of less than 5 for all of the observed variables (Bentler, 2005). Additionally, the Mardia's (1970) multivariate kurtosis ratio dropped from 18.3 to 1.848 for the basic model and from 15.489 to 1.622 later for the alternate model, which, in both cases, is less than 1.96 (Meyers et al., 2017). Thus, both the univariate and multivariate normalities conditions were met, and CFA was suitable to be run on our final sample of 507 cases. Further, we conducted exploratory factor analysis (EFA) with Varimax rotation (Mahmoud \& Khalifa, 2015), using SPSS v. 23, after the basic model had exhibited poor fit to our data. Profiling our participants, the majority of our sample were males $(57 \%)$, educated to a postgraduate level $(63 \%)$, with five years or more experience in their current position (73\%). Eventually, one sample T-test was executed, using SPSS v. 23, to evaluate the final dimensions of the measurement model against the neutral value (i.e., 3). 


\section{Results}

Using structural equation modelling (SEM), we test the theoretically hypothesised structure stating TQM-Benchmarking measurement model as a six-factor variate. We employ a set of model-fit indices to judge the validity of the measurement model. The adopted fit-indices set includes the following statistics: $\chi^{2} / \mathrm{df}=$ Chi-square divided by degrees of freedom (Mahmoud \& Grigoriou, 2017), RMSEA = Root Mean Square Error of Approximation (MacCallum, Browne \& Sugawara, 1996), SRMR = Standardised Root Mean Square Residual (Byrne, 2006; Hu \& Bentler, 1995), CFI = Comparative Fit Index (Bentler, 1990), and TLI = Tucker-Lewis index (Tucker $\&$ Lewis, 1973). Our results $\left(\chi^{2} / \mathrm{df}=3.127>3\right.$; RMSEA $=.102>.08 ;$ SRMR $=$ $.0686<.08 ; \mathrm{CFI}=.787<.9 ;$ and TLI $=.758$ not close to .95$)$ show that all fit indices but SRMR demonstrate a poor fit of the basic measurement model to the collected data. We therefore reject Hypothesis 2 and conclude that an exploratory factor analysis (EFA) is needed to explore the dimensionality of the TQM-Benchmarking measurement model before running another CFA (Byrne, 2010). Accordingly, we run EFA to elicit a new set of dimensions for TQM-Benchmarking measurement model before running another CFA. Our results (Table 1) show that the items of the TQM-Benchmarking measurement model are loaded on four factors. We thus performed another CFA for the alternate four-factor measurement model (see Figure 2).

\section{PLACE TABLE 1 ABOUT HERE}

The fit indices of the second CFA (i.e., $\chi^{2} / \mathrm{df}=1.915<3$; RMSEA $=.067<.08$; SRMR $=.0471<.08 ; \mathrm{CFI}=.941>.9 ;$ and $\mathrm{TLI}=.928$ very close to .95$)$ support the results of the EFA and we conclude that TQM-Benchmarking model is a four-factor variate composed of LMC = Leadership and Management Commitment; PQMS = Partnership Quality Management for 
Sustainability, PMLCI = Process management, Learning and Continuous Improvement; and $\mathrm{UQI}=$ Use of Quality Information. Furthermore, the reliability tests were run for the new four dimensions and yielded Cronbach's alpha values higher than .7 (in Table 2), suggesting that the new TQM-Benchmarking model is deemed to be internally consistent (Nunnally \& Bernstein, 1994). The one-sample T-test is run for each of the four validated dimensions to evaluate the levels of TQM-Benchmarking demonstrated by the participants. The results of Ttest indicate that the participants report positive levels of TQM-Benchmarking within their organizations suggesting that the participants' organisations tend to show high levels of leadership and management commitment $(\mathrm{t}=27.035, \mathrm{p}<.0001)$, and partnership quality management for sustainability $(\mathrm{t}=17.622, \mathrm{p}<.0001)$ accompanied with effective and efficient practices of process management, learning and continuous improvement $(\mathrm{t}=21.310, \mathrm{p}<.0001)$ as well as quality information $(\mathrm{t}=17.843, \mathrm{p}<.0001)$. This leads to conclude that Hypothesis 1 is accepted.

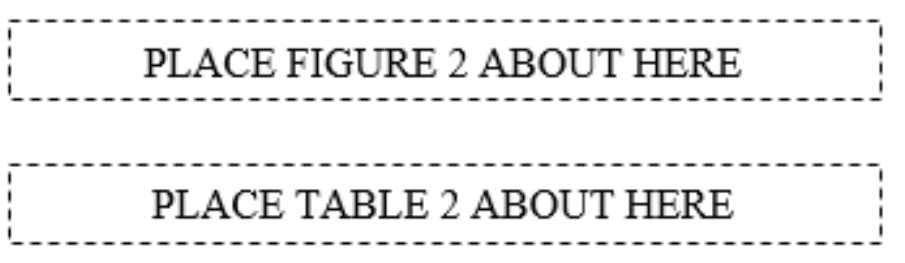

\section{Discussion}

Although the humanitarian sector has recently received attention in the implementation of quality driven initiatives, with a myriad of initiatives developed to optimize the quality performance and increase the impact of interventions on people's lives, there is no consensus on any one specific approach to be considered superior. Consequently, scholars took the initiative to find an appropriate model to help non-profit organizations maximize the people's benefit from the interventions. To this extend, qualitative surveys and extensive literature reviews have led researchers to identify the TQM-Benchmarking model as the one that has 
gained practice among international humanitarian actors involved with INGOs (Sweis et al., 2016). Our study was designed to present empirical evidence concerning this TQMBenchmarking model.

The results show that the TQM-Benchmarking measure is a four-dimensional structure instead of the originally suggested six-dimensional one (thus Hypothesis 2 is rejected). The two rejected dimensions are Beneficiary's Engagement and Participation (BEP); and Human Resource Focus (HRF). While it is perplexing that survey, respondents did not find these two critical components of TQM relevant and significant to their work, we believe that the two missing dimensions are indeed important, but participants captured them within other variables. In fact, it appears that the rejected dimensions are embedded in the four reformed dimensions that our analysis arrived at. As Sheehan (1998) argues, the human resource focus is about concern for people and this encapsulates both beneficiaries and employees whose interest in and subject of compassion are tightly intertwined. Therefore, the four dimensions cannot be articulated outside of or be divorced from the people concern. For example, the high level of leadership dimension we found is linked to leadership of people and activities. Some research has gone as far as suggesting only two dimensions - 'results' and 'enablers' (Elissetche, 2002). However, we found the two-way approach restrictive in providing systematic benchmarking and adequate guide for organisations that aspire to implement TQM approaches. The four dimensions identified here are significant for lean management practices in INGOs which require prompt intervention encapsulating speed and efficiency in the delivery of compassionate action. Stone (2012) and Rother \& Shook (1999) see lean thinking in action as a process of "continuous identification and elimination of waste from an organisation's processes, leaving only value-added activities in the value stream" (Stone, 2012). Often heavy bureaucratic structures and processes consume significant amounts of managers' and professional time in NGOs and obfuscate key project objectives, leading to inefficiencies 
(Narayana, 1992). Our results also reveal that the participants have positive levels of practice regarding the four accepted dimensions. Our reduced framework of four TQM dimensions for INGOs contributes to resolve one of the key barriers - theoretical complexity - that these organisations face in applying TQM principles (Dahlgaard, et al., 2013). Accordingly, Hypothesis 1 is accepted and confirmed that the UN agencies apply a high level of TQM practice.

\section{Conclusion}

This study investigated the validity of the previously proposed theoretical TQM-Benchmarking model that was created to improve the quality of humanitarian assistance. We tested the model based on six suggested dimensions to reveal that only four dimensions are valid in lieu of six: 1) Leadership and Management Commitment-LMC; 2) Process Management, Learning, and Continuous, Improvement-PMLCI; 3) Use of Quality Information-UQI; 4) Partnership Quality, Management for Sustainability-PQMS.

From our results, we note that organizations should address the issue of quality during the whole project cycle. As Donini (1995) argues, international NGOs are no longer merely providers of information or services, but they gain importance in the context of policy shaping. This evolved role of NGOs demands active and proactive actions to stress quality outcomes by senior management and all relevant employees (Hack-polay \& Igwe, 2018). It is noteworthy, that the results of this study show the important role of local partners that help in carrying out the planned activities with the identified quality. For this purpose, the capacity of the partners and their staff in terms of quality and accountability should be given attention to make certain that their work achieves organizational objectives. Finally, we conclude that the quality goals 
are achieved by shared efforts and joint responsibility of management with all internal and external stakeholders.

\section{Limitations and future research}

For generalizability, this study recommends replication in other countries where the UN agencies work to provide humanitarian assistance in order to confirm the empirical evidence related to the TQM-Benchmarking model and its dimensions. Conducting a similar study in another geographic region may help to shed additional light on the reasons for rejecting the BEP and the HRF dimensions of the basic model as cultural differences could play a role in how TQM is implemented by UN organizations working in humanitarian relieve settings throughout the world. Moreover, this study recommends conducting a qualitative survey to discuss in-depth the drivers and barriers of implementing the TQM-Benchmarking model within the UN agencies working in the Middle East and beyond. 


\section{References:}

AbouAssi, K., Makhlouf, N., \& Whalen, P. (2016). NGOs' resource capacity antecedents for partnerships. Nonprofit Management and Leadership, 26(4), 435-451.

Al-Dhaafri, H., \& Al-Swidi, A. (2016). The impact of total quality management and entrepreneurial orientation on organizational performance. International Journal of Quality \& Reliability Management, 33(5), 597-614.

Altayeb, M., \& Alhasanat, M. (2014). Implementing Total Quality Management (TQM) in the Palestinian Construction Industry. International Journal of Quality and Reliability Management, 31(8), 878-887.

Analoui, F., \& Samour, A. (2012). Strategic management: the case of NGOs in Palestine. Management Research Review, 35(6), 473- 489.

Baidoun, S. D., Salem, M. Z. \& Omran, O. A. (2018) Assessment of TQM implementation level in Palestinian healthcare organizations: The case of Gaza Strip hospitals. The TQM Journal 30(2), 98-115.

Bentler, P. (1990). Comparative fit indexes in structural models. Psychological Bulletin, 107, 238-246.

Bentler, P. (2005). EQS 6 Structural Equations Program Manual. Encino: Multivariate Software.

Boateng-Okrah, E., \& Fening, F. (2012). TQM implementation: a case of a mining company in Ghana. Benchmarking: An International Journal, 19(6), 743-759.

Byrne, B. (2010). Structural Equation Modeling with AMOS: Basic Concepts, Applications, and Programming. New York: Routledge, Taylor \& Francis Group, LLC. 
Byrne, B. M. (2006). Structural equation modeling with EQS: Basic concepts, applications, and programming ( $2^{\text {nd }}$ ed.). Mahwah, NJ: Erlbaum.

Cairns, B., Harris, M., Hutchison, R., \& Tricker, M. (2005). Improving performance? The adoption and implementation of quality systems in UK nonprofits. Nonprofit Management and Leadership, 16(2), 135-151.

Campbell, S., DiGiuseppe, M. \& Murdie, A. (2019) International Development NGOs and Bureaucratic Capacity: Facilitator or Destroyer? Political Research Quarterly, 72(1) 3-18.

Cheng, C. Y., \& Chang, P. Y. (2012). Implementation of the Lean Six Sigma framework in non-profit organisations: A case study. Total Quality Management \& Business Excellence, 23(3-4), 431-447.

Coate, B., Handmer, J., \& Choong, W. (2006). Taking care of people and communities. Disaster Prevention and Management: An International Journal, 15(1), 135-145.

Daar, A. et al. (2018) Grand challenges for humanitarian aid Fund and study these priorities for natural and social sciences to meet a gaping need. Nature 5 5, 16 9-173

Dahlgaard, J. J. et al. (2013) Business excellence models: limitations, reflections and further development. Total Quality Management \& Business Excellence, 24(5-6), 519538.

Dany, C. \& Schneiker, A. (2015) International NGOs: Experts, advocates and activists. Development \& Cooperation, https://www.dandc.eu/en/article/international-ngosplay-various-roles-global-politics-their-scope-influence-varies-do-their, accessed 26/03/2019 
Development Initiatives (2016) Global Humanitarian Assistance Report 2016 http://devinit.org/wp-content/uploads/2016/06/Global-Humanitarian-AssistanceReport-2016.pdf, accessed 26/03/2019

Donini, A. (1995) The bureaucracy and the free spirits: Stagnation and innovation in the relationship between the UN and NGOs. Third World Quarterly, 16(3), 421-440.

Elissetche, O. (2002) A Business Model to Assess and Improve Effectiveness in Nonprofits TQM Approach in the Nonprofit Sector in Argentina. Conference Nonprofit Organizational Effectiveness \& Performance Challenges \& Advances in Theory and Practice, The Midwest Center for Nonprofit Leadership (MCNL), University of Missouri - Kansas City April 18-19

Ferris, E. (2005). Faith-based and secular humanitarian organizations. International review of the Red Cross, 87(858), 311-325.

Fitzpatrick, T., \& Molloy, J. (2014). The role of NGOs in building sustainable community resilience. International Journal of Disaster Resilience in the Built Environment, $5(3), 292-304$.

Fonseca, L. (2015). From Quality Gurus and TQM To ISO 9001:2015: A Review of Several Quality Paths. International Journal for Quality Research, 9(1), 167-180.

Gherbal, N., Shabani, A., Saidani, M., \& Sagoo, A. (2012). Critical Success Factors of Implementing Total Quality Management in Libyan Organisations. International Conference on Industrial Engineering and Operations Management, (pp. 80-89). Istanbul. 
Griekspoor, A., \& Sondorp, E. (2001). Enhancing the quality of humanitarian assistance: Taking stock and future initiatives. Prehospital and disaster medicine, 16(4), 209215.

Hack-polay, D., \& Igwe, P. (2018). 'Beyond Words and Rhetoric-Small Voluntary Organisations and Effective Refugee Integration in the Communities. Journal of Enterprising Communities: People and Places in the Global Economy.

HAP - Humanitarian Accountability Partnership. (2010). The 2010 HAP Standard in Accountability and Quality Management. Geneva: HAP international. Retrieved March 18, 2018, from CHS Alliance: https://www.chsalliance.org/files/files/Resources/Standards/2010-hap-standardin-accountability.pdf

Horng, C., \& Huarng, F. (2002). TQM adoption by hospitals in Taiwan. Total Quality Management, 13(4), 441-463.

Hu, L.-T., \& Bentler, P. (1995). Evaluating model fit. In R. Hoyle (Ed.), Structural Equation Modeling: Concepts, Issues, and Applications. Thousand Oaks, CA: Sage.

Hughes, J. P. (2013). A new cost efficiency measure for not-for-profit firms: evidence of a link between inefficiency and large endowments. Atlantic Economic Journal, 41(3), 279-300.

Jacobs, A. (2011). Five pillars: improving quality \& impact. Retrieved March 18, 2018, from NGO Performance: https://ngoperformance.org/2011/04/19/five-pillarsimproving-quality-impact/ 
Kearns, K. P., Krasman, R. J., \& Meyer, W. J. (1994). Why nonprofit organizations are ripe for total quality management. Nonprofit Management and Leadership, 4(4), 447460.

Lassiter, V. (2007). The Role of Process Improvement in the Non-profit Organization. Retrieved March 18, 2018, from University of Pennsylvania: https://repository.upenn.edu/cgi/viewcontent.cgi?referer=\&httpsredir=1\&article= 1004\&context=od_theses_msod

MacCallum, R., Browne, M., \& Sugawara, H. (1996). Power analysis and determination of sample size for covariance structure modeling. Psychological Methods, 1(2), 130149.

Mahmoud, A. B., \& Grigoriou, N. (2017). When empathy hurts: Modelling university students' word of mouth behaviour in public vs. private universities in Syria. Higher Education Quarterly, 71(4), 369-383.

Mahmoud, A. B., \& Khalifa, B. (2015). A confirmatory factor analysis for SERVPERF instrument based on a sample of students from Syrian universities. Education+ Training, 57(3), 343-359.

Mardia, K. V. (1970). Measures of multivariate Skewness and Kurtosis with applications. Biometrika, 57(3), 519-530.

McGoldrick, C. (2011) The future of humanitarian action: an ICRC perspective. International Review of the Red Cross 93(884), 965-991

Meyers, L., Gamst, G., \& Guarino, A. (2017). Applied multivariate research: Design and interpretation. Thousand Oaks, California: SAGE Publications, Inc. 
Murtala, L. (2012). Characteristics of Good Quality Information (ACCURATE). Retrieved March 18, 2018, from ACCA: Training course notes: http://accalecturenotes.blogspot.co.uk/2011/03/characteristics-of-goodquality.html

Narayana, E. A. (1992) Bureaucratization of non-governmental organizations: An analysis of employees' perceptions and attitudes. Public Administration and Development 12(2), 123-137

Nunnally, J., \& Bernstein, I. (1994). Psychometric theory. New York: McGraw Hill.

Paton, R., Foot, J. \& Payne, G. (2000) When happens when Nonprofits Use Quality Models for Self-Assessment? Nonprofit Management and Leadership 11(1), 21-34

Porter, T. (2003) The Interaction between Political and Humanitarian Action in Sierra Leone, 1995 to 2002. Geneva: Centre for Humanitarian Dialogue

Proulx, K., Hager, M., \& Klein, K. (2014). Models of collaboration between non-profit organizations. International Journal of Productivity and Performance Management, 63(6), 746-765.

Rathi, D., Given, L., \& Forcier, E. (2014). Interorganisational partnerships and knowledge sharing: the perspective of non-profit organizations (NPOs). Journal of Knowledge Management, 18(5), 867-885.

Ridder, H., Piening, E. P., \& Baluch, A. (2012). The Third Way Reconfigured: How and Why Non-profit Organizations are Shifting Their Human Resource Management. Voluntas: International Journal of voluntary \& Non-profit Organizations, 23(3), $605-635$. 
Ryan, C. and Irvine, H. (2012), "Not-for-profit ratios for financial resilience and internal accountability: a study of Australian international aid organisations", Australian Accounting Review, 22(2), 177-194.

Saavedra, L. and Knox-Clarke P. (2015). Working together in the field for effective humanitarian response. ALNAP Working Paper. London: ALNAP/ODI.

Sheehan, J. (1998) NGOs and participatory management styles: a case study of CONCERN Worldwide, Mozambique. International Working Paper Series (2). Centre for civil society, London school of economics and Political Science, London, UK. ISBN $075301257 X$

Steketee, E. (2010). Process management as a lever for managing social problems. The TQM Journal, 22(4), 379-385.

Stirrat, J. (2006). Competitive humanitarianism Relief and the tsunami in Sri Lanka. Anthropology Today 22(5), 11-16

Stone, K. B. (2012) Four decades of lean: a systematic literature review", International Journal of Lean Six Sigma. 3(2), 112-132.

Suykens, B., De Rynck , F. \& Verschuere, B. (2018) Nonprofit organizations in between the nonprofit and market spheres: Shifting goals, governance and management? Nonprofit Management and Leadership, https://doi.org/10.1002/nml.21347

Sweis, R., Saleh, F., Dahiyat, S., Sweis, N., Saleh, R., \& Diab, H. (2016). Benchmarking of TQM practices in INGOs: a literature review. Benchmarking: An International Journal, 23(1), 236-261.

The Core Humanitarian Standard. (2014). Core Humanitarian Standard on Quality and Accountability. CHS Alliance, Group URD and the Sphere Project. Retrieved 
March

18 ,

2018

from

https://corehumanitarianstandard.org/files/files/Core\%20Humanitarian\%20Stand ard\%20-\%20English.pdf

Tickle, M., Mann, R., \& Adebanjo, D. (2016). Quality paper deploying business excellence success factors for high performance. International Journal of Quality \& Reliability Management, 33(2), 197-230.

Valmohammadi, C. (2011). The impact of TQM implementation on the organizational performance of Iranian manufacturing SMEs. The TQM Journal, 23(5), 496-509.

Vaux, T. (2006) Humanitarian trends and dilemmas. Development in Practice, 16(3-4), 240254.

Wellens, L., \& Jegers, M. (2014). Beneficiary participation as an instrument of downward accountability: A multiple case study. European Management Journal, 32(6), 938949.

West, S. G., Finch, J. F., \& Curran, P. J. (1995). Structural equation models with nonnormal variables: Problems and remedies. In R. Hoyle (Ed.), Structural equation modeling: Concepts, issues, and applications (pp. 56-75). Thousand Oaks, CA: Sage.

Wienclaw, R. A. (2017, April). Operations and Business Process Management. Retrieved March 18, 2018, from EBSCO Research Starters: http://connection.ebscohost.com/c/essays/27577979/operations-business-processmanagement

Yong, J., \& Wilkinson, A. (2001). Rethinking total quality management. Total Quality Management, 247-258. 
Zbaracki, M. (1998). The rhetoric and reality of total quality management. Administrative science quarterly, 43(3), 602-636. 


\section{Table 1: EFA results}

\section{Rotated Component Matrix}

\begin{tabular}{|c|c|c|c|c|}
\hline \multirow{3}{*}{ Item } & \multicolumn{4}{|c|}{ Component } \\
\hline & LMC & UQI & PQMS & PMLCI \\
\hline & $\begin{array}{l}\text { Leadership and } \\
\text { Management } \\
\text { Commitment }\end{array}$ & $\begin{array}{l}\text { Use of Quality } \\
\text { Information }\end{array}$ & $\begin{array}{l}\text { Partnership Quality } \\
\text { Management for } \\
\text { Sustainability }\end{array}$ & $\begin{array}{l}\text { Process management, } \\
\text { Learning and Continuous } \\
\text { Improvement }\end{array}$ \\
\hline
\end{tabular}

LMC1 In the organization that I work for, the quality of beneficiary care is clearly identified in the organization's mission, vision and mandate

LMC2 In the organization that I work for, the accountability to beneficiaries, donors, and other stakeholders are well reflected in the organization's mission, vision, and mandate.

LMC3 In the organization that I work for focuses on establishing and delivering approved accountability framework for organization's staff and partners' staff

LMC4 In the organization that I work for, providing quality services is an integral part of the organizational culture

LMC5 In the organization that I work for, one of the key aspects of its organizational culture is promoting continuous improvement

LMC6 The organization that I work for aims at improving beneficiaries' care

PQMS1 The quality in the organization that I work for is the priority when it comes to selecting partners

PQMS2 In the organization that I work for, the quality standards and accountability frameworks are clearly communicated with its stakeholders 
Rotated Component Matrix

\section{Item}

PQMS3 The organization that I work for cares about building the capacity of the partner's staff in terms of quality standards

PQMS4 The organization that I work for cares about building the capacity of the partner's staff in terms of accountability frameworks

PMLCI1The organization that I work for, Standard Operating Procedures (SOPs) are well documented, approved,

communicated and agreed on

PMLCI2The organization that I work for conducts frequent internal reflections and audits

PMLCI3The organization that I work for tends to share monitoring and evaluation findings with the implementing parties

UQI1 The use of information is run in a timely and an accurate manner the organization that I work for

UQI2 The organization that I work for, the information relevant to intervention is updated in a timely manner

UQI3 The organization that I work for provides a constant collection of monitoring and evaluation data

UQI4 The organization that I work for uses a modern technology in data collection

\section{Component}

LMC

Management

Commitment

\section{UQI}

\section{Use of Quality \\ Information}

Leadership and
PQMS

Partnership Quality

Management for

Sustainability
PMLCI

Process management,

Learning and Continuous

Improvement
.707

.788 


\begin{tabular}{|c|c|c|c|c|c|}
\hline & \multirow{4}{*}{ Item } & \multicolumn{4}{|c|}{ Rotated Component Matrix } \\
\hline & & \multicolumn{4}{|c|}{ Component } \\
\hline & & & UQI & PQMS & PMLCI \\
\hline & & $\begin{array}{l}\text { Leadership and } \\
\text { Management } \\
\text { Commitment }\end{array}$ & $\begin{array}{l}\text { Use of Quality } \\
\text { Information }\end{array}$ & $\begin{array}{l}\text { Partnership Quality } \\
\text { Management for } \\
\text { Sustainability }\end{array}$ & $\begin{array}{l}\text { Process management, } \\
\text { Learning and Continuous } \\
\text { Improvement }\end{array}$ \\
\hline Eigenvalues & & 3.348 & 1.942 & 2.951 & 2.882 \\
\hline$\%$ of Variance & & 19.696 & 11.424 & 17.356 & 16.951 \\
\hline Cumulative $\%$ & & 19.696 & 65.427 & 37.052 & 54.003 \\
\hline
\end{tabular}


Table 2: Inter-correlations and reliability test

\begin{tabular}{llccccc}
\hline Correlations & M & SD & Alpha & LMC & PQMS & PMLCI \\
\hline LMC & 4.06 & 0.56 & 0.85 & & & \\
PQMS & 3.76 & 0.62 & 0.82 & $.632^{* *}$ & & \\
PMLCI & 3.91 & 0.61 & 0.72 & $.599^{* *}$ & $.500^{* *}$ & \\
UQI & 3.79 & 0.64 & 0.85 & $.595^{* *}$ & $.569^{* *}$ & $.540^{* *}$ \\
\hline$* * \mathrm{P}<.001$ & & & & & &
\end{tabular}

$* * \mathrm{P}<.001$ 
Figures

Figure1: The basic measurement model

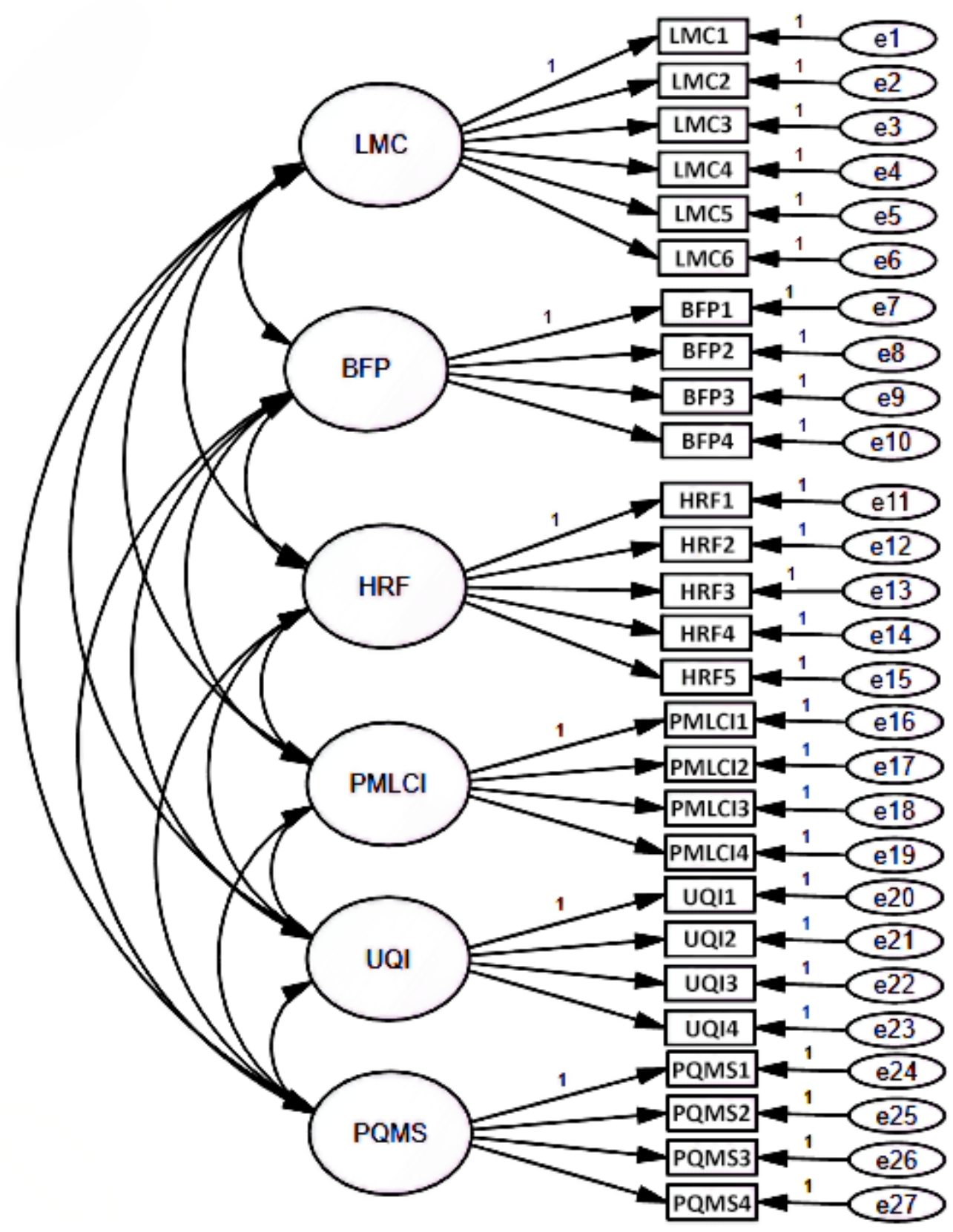


Figure 2: CFA Results for the alternate measurement model

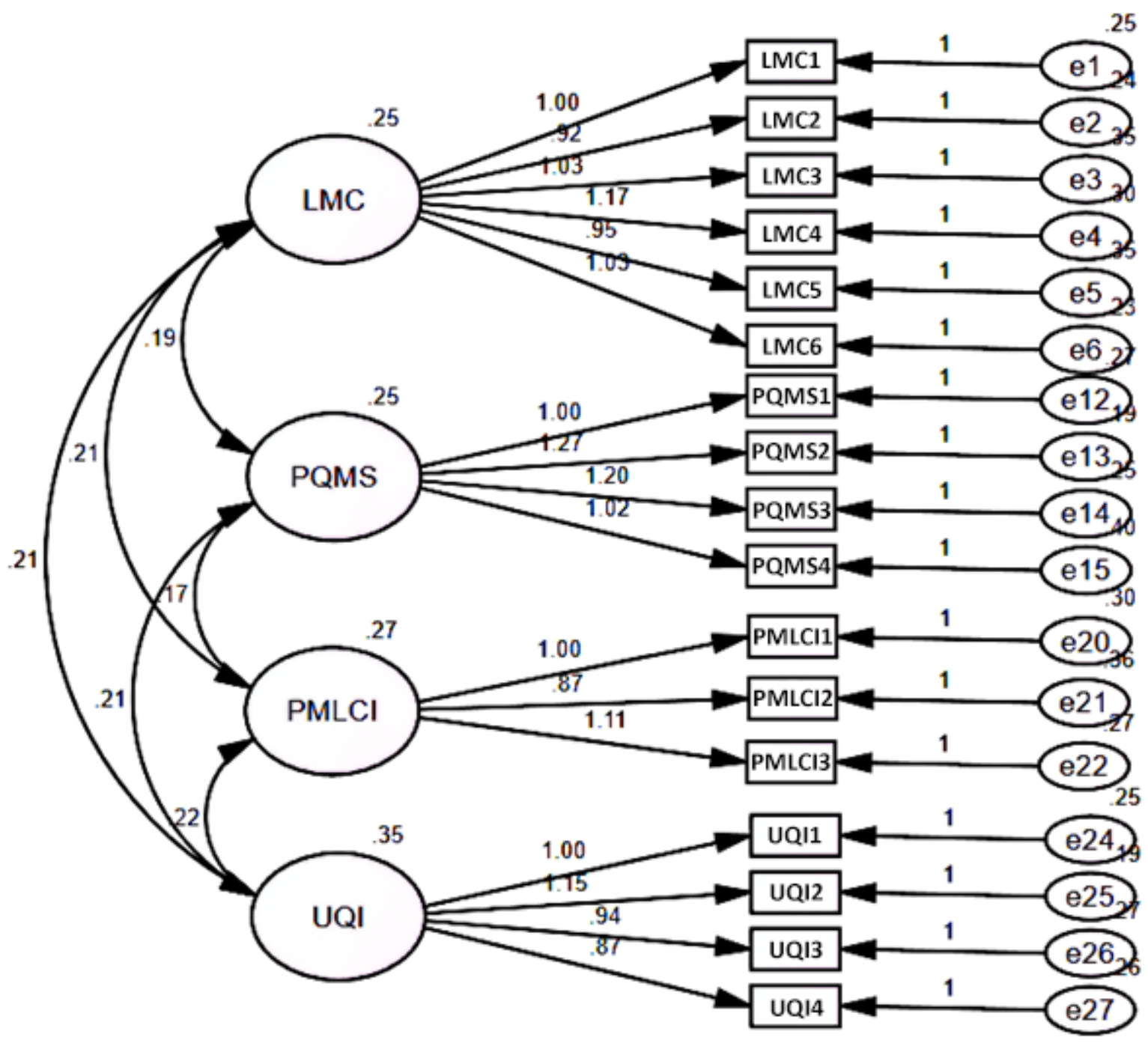

